
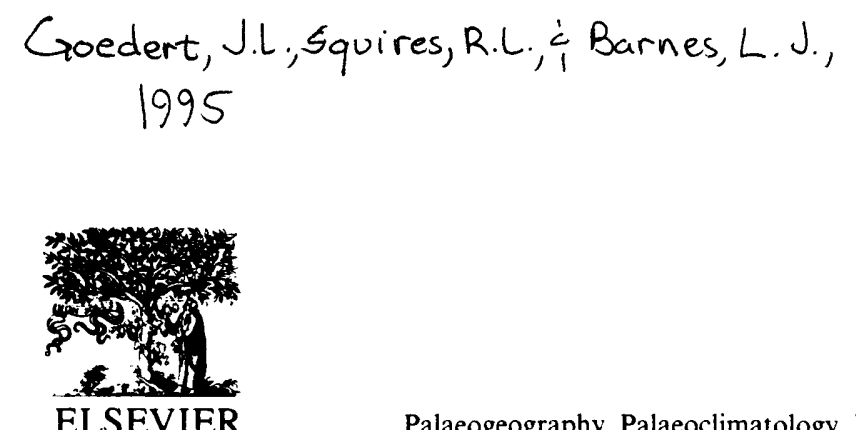

\title{
Paleoecology of whale-fall habitats from deep-water Oligocene rocks, Olympic Peninsula, Washington state
}

\author{
James L. Goedert ${ }^{\mathrm{a}, \mathrm{c}}$, Richard L. Squires ${ }^{\mathrm{b}}$, Lawrence G. Barnes ${ }^{\mathrm{c}}$ \\ ${ }^{a} 1520784$ th Avenue Ct. NW, Gig Harbor, WA 98329, USA \\ ${ }^{b}$ Department of Geological Sciences, California State, University, Northridge, CA 91330-8266, USA \\ ' Section of Vertebrate Paleontology, Natural History Museum of Los Angeles County, 900 Exposition Boulevard, \\ Los Angeles, CA 90007, USA
}

Received 9 August 1994; revised and accepted 7 Dcember 1994

\begin{abstract}
Fossil mollusks associated with eight Oligocene whales from the Makah and Pysht Formations on the northwestern part of the Olympic Peninsula, Washington, suggest that whale carcass sulfide production supported small numbers of some chemosymbiotic invertebrates as early as 30 million years ago. Thyasirid and modiolid bivalves usually dominate these very localized molluscan assemblages; lucinid and nuculanid bivalves, scaphandrid, naticid, and buccinid gastropods are rarely present; brachiopods were found once. These fossils include, tentatively, the first fossil record for the bivalve genus Idasola, and the first record of the bivalve Thyasira peruviana Olsson, outside of probable cold-seep deposits in South America.

Strata surrounding the fossil whales contain low diversity megafaunas that include rare deep-water gastropods and bivalves, large isopods, and localized cold-seep communities. The whale-fall assemblages differ significantly because of the presence of Idasola? sp. and Thyasira peruviana? and the absence of vesicomyid bivalves. Vertebrate carcasses have probably not contributed significantly to the dispersal of cold-seep and hydrothermal vent invertebrates. Seep/vent communities were well established much earlier than the evolution of cetaceans, and seep/vent invertebrates have not been found with carcasses of other large vertebrates.
\end{abstract}

\section{Introduction}

Communities of chemosymbiotic invertebrates were recently discovered associated with a decomposing whale carcass on the bathyal seafloor in the Santa Catalina Basin, southern California, in the eastern north Pacific Ocean (Smith et al., 1989; Allison et al., 1991). Decomposition of the whale carcass had created a sulfide-rich microenvironment that was inhabited by invertebrates, especially mollusks, probably supported by chemoautotrophic sulfur bacteria (Smith et al., 1989). McLean (1992) described limpets from this whale carcass, and coined the term "whale-fall habitat".
Deep-sea chemosymbiotic invertebrate communities were first found near geologically induced sulfide environments such as hydrothermal vents, cold-methane seeps, and petroleum seeps (Lonsdale, 1977; Suess et al., 1985; Kulm et al., 1986; Callender et al., 1990).

Fossils of probable whale carcass supported chemosymbiotic mollusks were first reported by Squires et al. (1991) and these are discussed in more detail here, supplemented by observations from newly available specimens. All are from Oligocene-age rocks on the Olympic Peninsula, Clallam County, Washington State (Figs. 1, 2). The fossil cetaceans are all as yet unprepared 


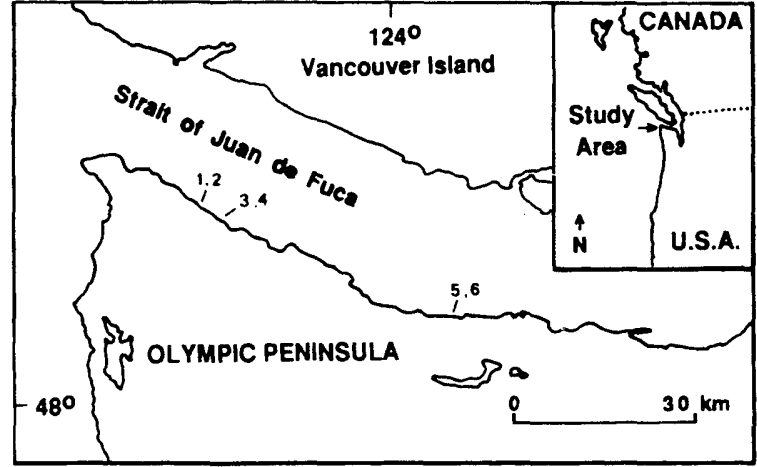

Fig. 1. Index map of the northwestern Olympic Peninsula, Washington State, showing fossil cetacean localities: $I=$ LACMVP 5983; 2 = LACMVP 5984; $3=$ LACMVP 5982; $4=$ CSUN 1579; $5=$ LACMVP 5412; $6=$ CSUN 1578.

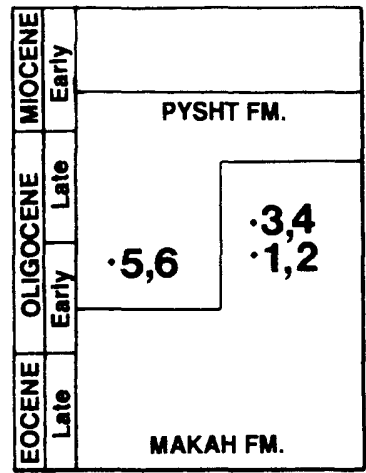

Fig. 2. Generalized correlation chart for fossil cetacean localities shown in Fig. 1.

specimens that probably represent undescribed taxa. Abbreviations used for specimen and locality numbers are: $L A C M V P=$ Section of Vertebrate Paleontology, Natural History Museum of Los Angeles County, Los Angeles, California; LACMIP = Section of Invertebrate Paleontology; CSUN = California State University, Northridge, California; JLG =J.L. Goedert field numbers. Field numbers denote recently collected, unprepared specimens in storage at LACMVP (except as noted); copies of JLG field notes are on file at LACMVP.

The study of modern and ancient deep-water whale-fall mollusk associations is still in a preliminary stage. This paper demonstrates that such associations are preserved in the fossil record and, it is hoped, will provide a stimulus for the search of additional examples worldwide.

\section{Oligocene whale-fall molluscan assemblages}

\subsection{Makah Formation}

Collecting in exposures of the Oligocene portion of the upper Eocene to upper Oligocene Makah Formation along the north shore of the Olympic Peninsula has, since 1983, produced 30 fossil whales. Some of these are nearly complete skeletons collected in situ, whereas others are partial skulls found in concretions that remain as erosional-lag materials on modern beach terraces.

The cetacean fossils are in concretions from different localities only in the upper part of the formation exposed between Shipwreck Point and the Sekiu River. Rocks in this part of the formation are hemipelagic siltstones and sandstones that were deposited at lower to middle-bathyal depths (Snavely et al., 1980) and are nearly barren of megafossils. Megafossils from these basin-plain and outer fan-fringe deposits include wood fragments, deep-water gastropods (Squires et al., 1991; Squires and Goedert, 1994), the deep-water bivalve Myonera (Goedert, in press), and large isopods (Wieder and Feldmann, 1989). Rare allochthonous masses of limestone contain an invertebrate assemblage that indicates cold-methane seeps supported localized chemosymbiotic molluscan communities on the shelf/slope near the basin that contained the whale carcasses (Goedert and Campbell, 1995). Benthic foraminifers from this part of the formation indicate an age ranging from late Eocene to late Oligocene (Snavely et al., 1980; Armentrout et al., 1983); however, mollusks support a late early to early late Oligocene age assignment (Squires and Goedert, 1994).

Preliminary examination revealed that four of the whales also have fossil mollusks in the matrix surrounding the bones (Table 1). Three of the whales were briefly discussed by Squires et al. (1991). One, LACMVP 131501, is a primitive mysticete (estimated body length $3 \mathrm{~m}$ ) found in situ west of the mouth of the Sekiu River. The anterior half of the skull was missing, the skeleton 
Table 1

Fossil whales and associated invertebrates from Oligocene rocks, Olympic Peninsula, Washington

\begin{tabular}{|c|c|c|}
\hline Cetacean specimen & Bivalves & $\begin{array}{l}\text { Gastropods and } \\
\text { brachiopods }\end{array}$ \\
\hline \multicolumn{3}{|l|}{ Makah Formation } \\
\hline $\begin{array}{l}\text { Primitive mysticete, } \\
\text { LACMVP } 131501, \\
\text { LACMVP loc. } 5982 .\end{array}$ & $\begin{array}{l}\text { Thyasira } \\
\text { peruviana? } \\
\text { Idasola? sp. } \\
\text { modiolids }\end{array}$ & $\begin{array}{l}\text { Scaphander sp. } \\
\text { naticid } \\
\text { buccinid }\end{array}$ \\
\hline $\begin{array}{l}\text { Primitive mysticete, } \\
\text { LACMVP 131502, } \\
\text { LACMVP loc. } 5983 .\end{array}$ & $\begin{array}{l}\text { Thyasira sp. } \\
\text { modiolids }\end{array}$ & \\
\hline $\begin{array}{l}\text { “Agorophiid” } \\
\text { odontocete, LACMVP } \\
\text { 131503, } \\
\text { LACMVP loc. } 5984 .\end{array}$ & $\begin{array}{l}\text { Lucinoma } \\
\text { hannibali? Clark }\end{array}$ & \\
\hline $\begin{array}{l}\text { Mysticete, field no. } \\
\text { JLG } 358 \text {, CSUN loc. } \\
1579 .\end{array}$ & $\begin{array}{l}\text { Thyasira } \\
\text { peruviana? } \\
\text { modiolids } \\
\text { nuculanid }\end{array}$ & \\
\hline $\begin{array}{l}\text { Pysht Formation } \\
\text { "Agorophiid" } \\
\text { odontocete, LACMVP } \\
133428 \text {, } \\
\text { LACMVP loc. } 5412 .\end{array}$ & modiolids & \\
\hline $\begin{array}{l}\text { Mysticete, field no. } \\
\text { JLG } 400 \text {, CSUN loc. } \\
1578 .\end{array}$ & $\begin{array}{l}\text { Thyasira bisecta } \\
\text { Conrad } \\
\text { Thyasira } \\
\text { peruviana? }\end{array}$ & naticid \\
\hline $\begin{array}{l}\text { Mysticete, field no. } \\
\text { JLG } 399 \text {, LACMVP } \\
\text { loc. } 5412 .\end{array}$ & $\begin{array}{l}\text { Thyasira } \\
\text { peruviana? }\end{array}$ & \\
\hline $\begin{array}{l}\text { Mysticete, field no. } \\
\text { JLG } 384 \text {, LACMVP } \\
\text { loc. } 5412 \text {. }\end{array}$ & Idasola? sp. & $\begin{array}{l}\text { small gastropod } \\
\text { brachiopods } \\
\text { (articulata) }\end{array}$ \\
\hline
\end{tabular}

was preserved ventral side up, and all of the bones were corroded prior to burial. Many modiolid bivalves, mostly poorly preserved, are present as articulated and disarticulated specimens in matrix surrounding the bones. Some are in masses in direct contact with the bones. A few of the modiolids are Idasola? sp. (Fig. 3). These specimens of Idasola? sp. along with others reported herein from the Pysht Formation, may represent the first fossil record for this genus because Idasola? bakeri (Dickerson), from Paleocene rocks in California, may not be a modiolid (Moore, 1983). A single articulated specimen of a thyasirid bivalve and a few poorly preserved gastropods were also in matrix surrounding this skeleton. Farther west, and stratigraphically lower, a small odontocete skeleton (estimated body length $1 \mathrm{~m}$ ), LACMVP 131503 , was found in situ and has a single articulated lucinid bivalve in its thoracic region. In addition, a cetacean braincase (LACMVP 131502) found as float, represents a primitive mysticete (estimated body length $3 \mathrm{~m}$ ). Matrix inside the skull has the mold of an articulated thyasirid bivalve that is too large to have entered the skull through the foramen magnum by means of some post-mortem taphonomic process; it is preserved where it grew. Another thyasirid was outside the skull, and poorly preserved modiolids are in matrix inside of and outside of the skull as well.

Nearby to LACMVP 131501, but stratigraphically higher, a concretion (field number JLG 358) was found in situ, and it contained some badly corroded mysticete rostral bones $( \pm 0.5 \mathrm{~m}$ long). This concretion was broken-up in order to recover the associated invertebrates, now in the CSUN collections. Modiolids, a single articulated thyasirid, and a single nuculanid bivalve were associated with these rostral bones.

\subsection{Pysht Formation}

The lower Oligocene to lowermost Miocene Pysht Formation directly overlies the Makah Formation on the north side of the Olympic Peninsula (Snavely et al., 1980). Like the Makah Formation examples, four fossil cetaceans collected from the Pysht Formation also have unusual invertebrate associations (Table 1). The four cetaceans are in concretions from deep-water strata exposed near the mouth of Murdock Creek, Clallam County, Washington. These strata are in the lower part of the formation and are mostly concretionary mudstone (Brown and Gower, 1958) deposited at bathyal depths (Rau, 1964). The mudstone is roughly middle Oligocene in age (Durham, 1944: p. 110; Goedert and Squires, 1993; Squires and Goedert, 1994), and is very similar lithologically and paleontologically to the upper part of the Makah Formation between the Sekiu River and Shipwreck Point. Megafossils are rare in this part of the Pysht Formation and include vertebrates 

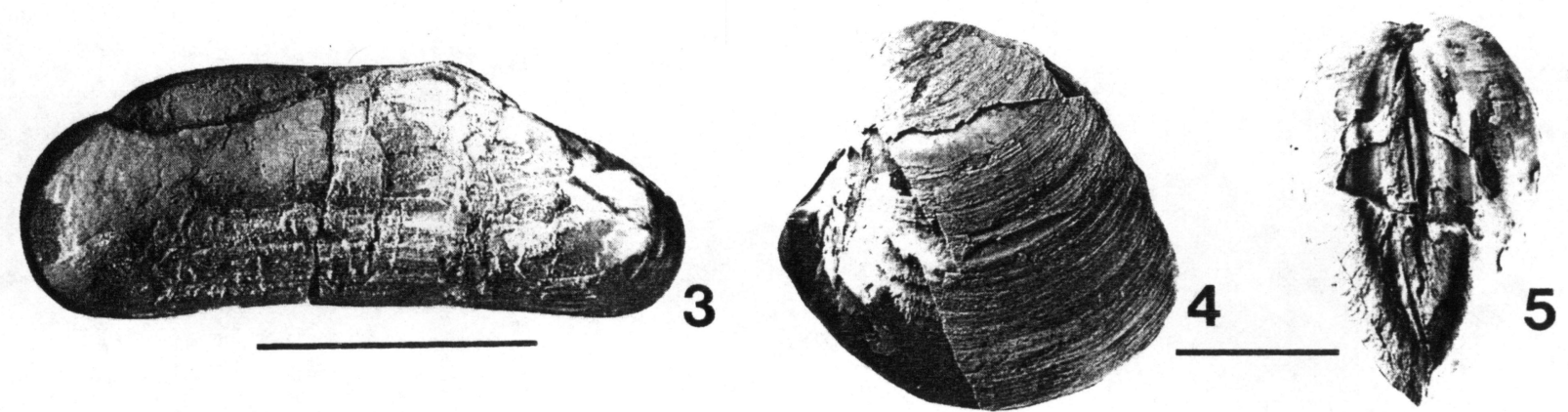

Fig. 3. Bivalves found associated with whale bones in the Makah and Pysht Formations. Scale bars represent $10 \mathrm{~mm}$. Idasola? sp., hypotype LACMIP 12337, right valve exterior, LACMVP loc. 5982 (=LACMIP loc. 6957). [JLG 107]

Fig. 4. Thyasira peruviana?, hypotype LACMIP 12336, left valve exterior, CSUN loc. 1578. (= LACMiP LOC.16883)

Fig. 5. T. peruviana?, posterior view of same specimen.

(Domning et al., 1986; Olson, 1980; Ray et al., 1994), some mollusks (Durham, 1944; Squires, 1989; Goedert and Squires, 1993; Squires and Goedert, 1994) and rare isopods (Wieder and Feldmann, 1989). A few sandstone beds, probably turbidites, have the trace fossil Zoophycos near their tops, and some contain transported shallowwater mollusks.

At locality CSUN 1578, near the first point west of the mouth of Murdock Creek, a partial cetacean skeleton (JLG 400; estimated body length $3 \mathrm{~m}$ ) was found in situ in thick-bedded mudstone that is otherwise barren of megafossils. The skeleton was approximately $15 \mathrm{~m}$ stratigraphically above a prominent thick turbidite sandstone. This skeleton consists of vertebrae and ribs (in CSUN collections); the skull and tail had been removed by erosion. A few naticid gastropods and several articulated thyasirid bivalves were found within $5-10 \mathrm{~mm}$ of the bones. Two of the bivalve specimens are similar to Thyasira peruviana Olsson, 1931.

Thyasira peruviana is known only from the Oligocene(?) Lomitos Cherts in Peru, where specimens are found in great numbers along with other thyasirids, as well as vesicomyid and solemyid bivalves, in an isolated exposure of cherty limestone (Olsson, 1931). The density of bivalves, their taxonomic composition, and the limestone rock type all strongly suggest that the Lomitos Cherts locality represents an ancient chemosymbiotic community. The Washington thyasirid (Figs. 4-5) is morphologically indistinguishable from some of the type specimens of $T$. peruviana illustrated by Olsson (1931, pl. 6, figs. 5, 7, 12) but differs from the other type specimens (Olsson, 1931, pl. 6, figs. $3,8,9)$ by not possessing a sharp ridge in the posterior-dorsal area.

Three fossils of cetaceans collected as float from mudstone exposed on the beach terrace near Murdock Creek, LACMVP loc. 5412, have invertebrates preserved in close association. One of these, LACMVP 133428, is the anterior portion of a small (estimated body length $2 \mathrm{~m}$ ) "agorophiid" odontocete cranium, which has a cluster of at least 11 very small, articulated modiolid bivalves preserved in carbonate matrix that fills the nasal opening.

The second cetacean specimen (JLG 399; in CSUN) is only a fragment of a concretion that originally contained a skull. The skull had been mostly eroded away, leaving only a 40 -mm-long portion of an earbone (bulla), some small bone fragments, and two articulated specimens (up to $20 \mathrm{~mm}$ height) of the bivalve resembling Thyasira peruviana.

The third specimen (JLG 384; in CSUN) was a fragment $(15 \times 15 \times 4 \mathrm{~cm})$ of a mysticete cranium and a $10-\mathrm{cm}$ long jaw fragment preserved in a piece of a large concretion. Two complete specimens of an articulate brachiopod were within 1-2 mm of the skull fragment; another was $72 \mathrm{~mm}$ away from the skull fragment and $15 \mathrm{~mm}$ from the jaw fragment. One small specimen of Idasola? 
sp. and a small gastropod were also present. Brachiopods have been reported from some ancient chemosymbiotic communities (Beauchamp and Savard, 1992; Campbell et al., 1993; M.R. Sandy, pers. comm.) but have not yet been reported in association with whale skeletons.

\section{Discussion}

The bivalves found in association with fossil cetaceans from the Makah and Pysht Formations are mostly articulated and all are unabraded, indicating that they were probably not transported prior to fossilization and are preserved in situ. A bivalve is preserved inside one of the Makah Formation cetacean skulls, where it must have lived and grown. The whales found in situ are, to a minor extent, disarticulated (i.e., teeth fallen out of skull and jaws, forelimb bones shifted, etc.); however, there is no evidence of disturbance of the skeletons by currents that would have been strong enough to transport the bivalves. We cannot envision any taphonomic process that would transport Thyasira peruviana? and Idasola? sp., during deposition of both the Makah and Pysht Formations, and then selectively deposit these bivalves only on whale skeletons and nowhere else.

The Oligocene whale carcasses were not used as substrates, except possibly by the modiolid bivalves. Other encrusting organisms (e.g., serpulid worms) are not present. Whale bone may be food for some gastropods (Marshall, 1987), but not for bivalves.

Martill et al. (1991) suggested that fossil vertebrate-invertebrate associations preserved in concretions might represent a preservational bias instead of a chemosymbiotic community. Concretions are locally extremely abundant in the upper part of the Makah Formation, but 99 percent of them are barren of megafossils. Modiolid bivalves have only been found in this part of the Makah Formation associated with whale bones, fossil wood (Squires et al., 1991), and transported cold-seep limestone (Goedert and Campbell, 1995). In both the Makah and Pysht Formation, Idasola? sp. has only been found associated with whale bone. Most of the bivalves found with the fossil cetaceans are too poorly preserved to be identified to species (Table 1); however, both of the bivalve genera Lucinoma and Thyasira have species that have been reported from modern and ancient methane seep communities (Campbell, 1989, 1990, 1992; Goedert and Squires, 1990; Squires and Goedert, 1991). The living bivalve Idasola washingtoniana has been found at hydrothermal vents and has also been found on sunken wood and whale skeletons in deep water (Smith et al., 1989). A chemosymbiotic relationship best explains the Oligocene whale-fall mollusk associations described herein.

Smith et al. (1989) suggested that decomposing whale carcasses on the ocean floor might have acted as "stepping stones" for the dispersal of vent faunas across an otherwise inhospitable deep-sea floor between widely separated hydrothermal vents and cold methane-seeps. Whales first appear in the fossil record during the early Eocene, about 50 million years ago, hence they evolved too late in geologic time to have facilitated the early distribution of the geologically more ancient vent or seep faunas. Martill et al. (1991), however, suggested that carcasses of other large marine vertebrates (sharks, fish, reptiles) may have provided stepping stones for dispersal of chemosymbiotic communities for at least the last 200 million years.

Mollusks have not yet been found associated with fossil skeletons of sharks, fish, or birds (some of which are as large or larger than some of the contemporaneous cetaceans) from the Makah and Pysht Formations. This is probably because carcasses of such animals do not contain as much oil as do those of cetaceans and, therefore, they do not generate sulfides for long periods of time. Approximately one-third of the oil content of a cetacean is contained within its skeleton (Slijper, 1962), which can provide a sulfide-rich reducing microenvironment for several years (Smith et al., 1989). It is uncertain whether or not large Paleozoic placoderm fish or large Mesozoic marine reptile and fish skeletons contained enough oil to have produced sulfides for enough time and with enough frequency to have sustained mollusk communities and acted as stepping stones as Martill et al. (1991) implied. None of the described ancient reptile deadfall assemblages contain invertebrates 
recognized from known chemosynthetic environments (Hogler, 1994).

The carcasses of fossil whales from the Makah and Pysht Formations probably had low levels of sulfide production because mollusks preserved in association are mostly small-sized and few in number. Sedimentation rates were low enough to allow the surfaces of bones not resting on sediment to be heavily corroded, and would not have inhibited growth of the mollusks. Modiolid bivalves were found in most of these mollusk/cetaceanbone associations (Table 1). Modiolids apparently survive near hydrothermal vents and cold-seeps when sulfide levels are low (Hessler et al., 1985) because they not only host endosymbiont sulfuroxidizing bacteria but also filter feed (Le Pennec et al., 1983). Some modern modiolid bivalves have been reported associated with whale bones (Dell, 1987; Marshall, 1987), but a chemosymbiotic relationship was first recognized by Smith et al. (1989).

Localized limestones that contain fossils of chemosymbiotic mollusks supported by cold methane-seeps are present in the same parts of the Makah and Pysht Formations that produced the cetaceans (Goedert and Squires, 1993; Goedert and Campbell, 1995). The limestones in the Makah Formation are allochthonous, and those from the lower part of the Pysht Formation have not yet been seen in situ. Significantly, Idasola? $\mathrm{sp}$. and Thyasira peruviana? have not been found in the cold-seep limestone or anywhere else in the Makah and Pysht Formations. Also, the vesicomyid bivalves that are abundant in the cold-seep limestone have not been found with the fossil cetacean bones. Vesicomyid bivalves were abundant on and around the modern whale carcass reported by Smith et al. (1989).

Fossils of a small scaphopod, Prodentalium sp., have been found associated with a Jurassic ichthyosaur (Martill, 1987), and Martill et al. (1991) stated that this scaphopod had also been found in late Eocene seep communities from Washington. Only one scaphopod has been recovered from one seep deposit (Goedert and Squires, 1990), and it is a species of Dentalium, not of Prodentalium as Martill et al. (1991) reported.

In conclusion, even though it has been demonstrated that a few chemosymbiotic invertebrates have utilized microenvironments created by decomposing animal carcasses, we agree with Tunnicliffe and Juniper (1990) that dispersal of vent faunas is mostly dependent upon seafloor spreading and/or larval distribution by currents. Some chemosymbiotic invertebrates may have prolonged larval stages (Lutz et al., 1980) that greatly aid in dispersal. Decomposing whale carcasses may be fortuitous sites for settlement and metamorphosis of these larvae, but the carcasses are probably not numerous enough to be a significant factor in dispersal. Recent work (Campbell and Bottjer, 1993; Campbell et al., 1993) has shown that ancient cold-seeps were just as common and widespread, at least since the Cretaceous, as they are today. The abundance of cold-seeps probably eclipsed any potential that animal carcasses may have had for affecting the dispersal of chemosymbiotic mollusks. In addition, because whales did not evolve until the early Eocene, they had no effect upon the earlier evolution of chemosymbiotic invertebrate communities.

\section{Acknowledgments}

We thank Ross and Marion Berglund, William R. Buchanan, John Cowan, Gail H. Goedert, and Albin Zukofsky II for assistance in the field. We thank Kathleen A. Campbell, C. Babin, and an anonymous reviewer for comments on the manuscript. Some fieldwork for this project was supported by a grant $(4439-90)$ from the National Geographic Society to the Natural History Museum of Los Angeles County Foundation in support of fossil cetacean research on the Olympic Peninsula.

\section{References}

Allison, P.A., Smith, C.R., Kukert, H., Deming, J.W. and Bennett. B.A., 1991. Deep-water taphonomy of vertebrate carcasses: a whale skeleton in the bathyal Santa Catalina Basin. Paleobiology, 17: 78-89.

Armentrout, J.M., Hull, D.A., Beaulieu, J.D. and Rau, W.W., 1983. Correlation of Cenozoic stratigraphic units of western Oregon and Washington. Ore. Dep. Geol. Mineral Ind. Oil Gas Invest., 7: 1-90. 
Beauchamp, B. and Savard, M., 1992. Cretaceous chemosynthetic carbonate mounds in the Canadian Arctic. Palaios, 7: 434-450.

Brown Jr., R.D. and Gower, H.D., 1958. Twin River Formation (redefinition), northern Olympic Peninsula, Washington. Bull. Am. Assoc. Pet. Geol., 42: 2492-2512.

Callender, W.R., Staff, G.M., Powell, E.N. and Macdonald, I.R., 1990. Gulf of Mexico hydrocarbon seep communities $\mathrm{V}$. Biofacies and shell orientation of autochthonous shell beds below storm wave base. Palaios, 5: 2-14.

Campbell, K.A., 1989. A Mio-Pliocene methane seep fauna and associated authigenic carbonates in shelf sediments of the Quinault Formation, SW Washington. Geol. Soc. Am. Abstr. with Programs, 21: A290.

Campbell, K.A., 1990. Ancient cold seep biotas along the NE Pacific convergent margin: a Mio-Pliocene example from SW Washington, USA. Geol. Assoc. Can. Abstr. with Programs, 15: A20.

Campbell, K.A., 1992. Recognition of a Mio-Pliocene cold seep setting from the northeast Pacific convergent margin, Washington, U.S.A. Palaios, 7: 422-433.

Campbell, K.A. and Bottjer, D.J., 1993. Fossil cold seeps (Jurassic-Pliocene) along the convergent margin of western North America. Natl. Geogr. Res. Explor., 9: 326-343.

Campbell, K.A., Carison, C. and Bottjer, D.J., 1993. Fossil cold seep limestones and associated chemosymbiotic macroinvertebrate faunas, Jurassic-Cretaceous Great Valley Group, California. In: S.A. Graham and D.R. Lowe (Editors), Advances in the Sedimentary Geology of the Great Valley Group, Sacramento Valley, California. Soc. Econ. Paleontol. Mineral. Pac. Sect. Book, 73: 37-50.

Dell. R.K., 1987. Mollusca of the family Mytilidae (Bivalvia) associated with organic remains from deep water off New Zealand, with revisions of the genera Adipicola Dautzenberg, 1927 and Idasola Iredale, 1915. Natl. Mus. New Zealand Rec., 3: 17-36.

Domning, D.P., Ray, C.E. and McKenna, M.C., 1986. Two new Oligocene desmostylians and a discussion of Tethytherian systematics. Smithson. Contrib. Paleobiol., 59: $1-56$.

Durham, J.W., 1944. Megafaunal zones of the Oligocene of northwestern Washington. Univ. Calif. Publ. Bull. Dep. Geol. Sci., 27: 101-212.

Goedert, J.L., in press. First fossil record for Myonera (Bivalvia: Cuspidariidae). Veliger.

Goedert, J.L. and Campbell, K.A., 1995. An early Oligocene chemosynthetic community from the Makah Formation, northwestern Olympic Peninsula, Washington. Veliger, 38: $22-29$.

Goedert, J.L. and Squires, R.L., 1990. Eocene deep-sea communities in localized limestones formed by subductionrelated methane seeps, southwestern Washington. Geology, 18: $1182-1185$.

Goedert, J.L. and Squires, R.L., 1993. First Oligocene records of Calyptogena (Bivalvia: Vesicomyidae). Veliger, 36: 72-77.

Hessler, R.R., Smithey Jr., W.M. and Keller, C.H., 1985. Spatial and temporal variation of giant clams, tube worms and mussels at deep-sea hydrothermal vents. In: M.L. Jones (Editor), Hydrothermal Vents of the Eastern Pacific: an Overview. Bull. Biol. Soc. Wash., 6: 411-428.

Hogler, J.A., 1994. Speculations on the role of marine reptile deadfalls in Mesozoic deep-sea paleoecology. Palaios, 9: 42-47.

Kulm, L.D. and 13 others, 1986. Oregon subduction zone: venting, fauna, and carbonates. Science, 231: 561-566.

Le Pennec, M., Lucas, A. and Petit, H., 1983. Etudes préliminaires sur un Mytilidae des sources hydrothermales du Pacifique. Haliotis, 13: 69-82.

Lonsdale, P., 1977. Clustering of suspension-feeding macrobenthos near abyssal hydrothermal vents at oceanic spreading centers. Deep-Sea Res., 24: 857-863.

Lutz, R.A., Jablonski, D., Rhoads, D.C. and Turner, R.D., 1980. Larval dispersal of a deep-sea hydrothermal vent bivalve from the Galapagos Rift. Mar. Biol., 57: 127-133.

Marshall, B.A., 1987. Osteopeltidae (Mollusca: Gastropoda): a new family of limpets associated with whale bone in the deep-sea. J. Mollusc. Stud., 53: 121-127.

Martill, D.M., 1987. A taphonomic and diagenetic case study of a partially articulated ichthyosaur. Palaeontology, 30: 543-555.

Martill, D.M., Cruikshank, A.R.I. and Taylor, M.A., 1991 Dispersal via whale bone. Nature, 351: 193.

McLean, J.H., 1992. Cocculiniform limpets (Cocculinidae and Pyropeltidae) living on whale bone in the deep sea off California. J. Mollusc. Stud., 58: 401-414.

Moore, E.J., 1983. Tertiary marine pelecypods of California and Baja California: Nuculidae through Malleidae. U.S. Geol. Surv. Prof. Pap., 1228-A: 1-108.

Olson. S.L., 1980. A new genus of penguin-like pelecaniform bird from the Oligocene of Washington (Pelecaniformes: Plotopteridae). In: K.E. Campbell (Editor), Papers in Avian Paleontology honoring Hildegarde Howard. Nat. Hist. Mus. Los Angeles Cty. Contrib. Sci.. 330: 51-57.

Olsson, A.A., 1931. Contributions to the Tertiary paleontology of northern Peru: part 4, the Peruvian Oligocene. Bull. Am. Paleontol., 17: 97-264.

Rau, W.W.. 1964. Foraminifera from the northern Olympic Peninsula, Washington. U.S. Geol. Surv. Prof. Pap.. 374-G: G1-G33.

Ray, C.E., Domning, D.P. and McKenna, M.C., 1994. A new specimen of Behemotops proteus (Order Desmostylia) from the marine Oligocene of Washington. In: A. Berta and T.A. Deméré (Editors), Contributions in Marine Mammal Paleontology honoring Frank C. Whitmore Jr. San Diego Soc. Nat. Hist. Proc., 29: 205-222.

Slijper, E.J., 1962. Whales. Basic Books, New York, 475 pp.

Smith, C.R., Kukert, H., Wheatcroft, R.A., Jumars, P.A. and Deming, J.W., 1989. Vent fauna on whale remains. Nature, 341: 27-28.

Snavely Jr., P.D., Niem, A.R., Macleod, N.S., Pearl, J.E. and Rau, W.W., 1980. Makah Formation-a deep-marginalbasin sequence of late Eocene and Oligocene age in the northwestern Olympic Peninsula, Washington. U.S. Geol. Surv. Prof. Pap., 1162-B: 1-28. 
Squires, R.L., 1989. Pteropods (Mollusca: Gastropoda) from Tertiary formations of Washington and Oregon. J. Paleontol., 63: $443-448$.

Squires. R.L. and Goedert, J.L., 1991. New late Eocene mollusks from localized limestone deposits formed by subduction-related methane seeps, southwestern Washington. J. Paleontol., 65: 412-416.

Squires, R.L. and Goedert, J.L., 1994. A new species of the volutid gastropod Fulgoraria (Musashia) from the Oligocene of Washington. Veliger. 37: 400-409.

Squires. R.L., Goedert, J.L. and Barnes, L.G., 1991. Whale carcasses. Nature, 349: 574.
Suess, E., Carson, B., Ritger, S.D., Moore, J.C., Jones, M.L., Kulm, L.D. and Cochrane, G.R., 1985. Biological communities at vent sites along the subduction zone off Oregon. In: M.L. Jones (Editor), Hydrothermal Vents of the Eastern Pacific: an Overview. Bull. Biol. Soc. Wash., 6: 475-484.

Tunnicliffe, V. and Juniper, S.K.. 1990. Cosmopolitan underwater fauna. Nature, 344: 300.

Wieder, R.W. and Feldmann, R.M., 1989. Palaega goedertorum, a fossil isopod (Crustacea) from late Eocene to early Miocene rocks of Washington State. J. Paleontol., 63: 73-80. 